\section{Євген ЦИБУЛЕНКО}

\section{Ксенія ЛОБОДА}

\section{Українська енциклопедія міжнародного права у світовому контексті}

Рецензія на «Енциклопедію міжнародного права». У 3 т.; редкол.: Ю. С. Шемшученко, В. Н. Денисов (співголови) та ін.; Інститут держави і права ім. В.М. Корецького НАН України. - Київ: Академперіодика, 2014, 2017, 2019.

Вихід у світ «Енциклопедії міжнародного права» у трьох томах є надзвичайною подією в розвитку вітчизняної науки міжнародного права. Не багато країн світу ще й сьогодні можуть похвалитися існуванням своєї школи міжнародного права. Ще менше тих, в яких розроблено власні підручники міжнародного права (по суті, видання підручника з цього предмету є свідченням створення такої національної школи). Іще менша кількість держав видають власну періодику з міжнародного права (журнали, альманахи, щорічники тощо). За словами доктора юридичних наук, професора В.Буткевича, «по-справжньому держава стає незалежною, коли ії наукові і практичні фахівці здатні продукувати наукове бачення міжнародного права, що відповідає національним інтересам. .... при цьому менше сорока відсотків держав наразі спроможні видавати національні підручники міжнародного права, а ще менше половини з них досягли такого рівня розвитку науки, що здатні видавати власні Щорічники міжнародного права. Ті, кому це виявилося не під силу, домовляються про регіональні видання» [1, С. 36, 37]. При цьому такі складності стосуються порівняно поширених жанрів міжнародно-правової літератури (підручники, періодика). У той же час, одним з найскладніших жанрів $є$ енциклопедичний. Саме тому, вкрай мало країн здатні на відповідні видання.

Достатньо згадати, що за весь період існування СРСР, там було видано лише стислий «Словник міжнародного права» [2], який зазнав перевидань, і який містив лише короткі дефініції загальновідомих термінів $з$ міжнародного права.

Більш грунтовно до питання видання Енциклопедії з міжнародного права підійшов німецький Інститут Макса Планка. Там уперше протягом 1992-2000 років було підготовлено (і опубліковано у видавництві «Elsevier») чотиритомну Енциклопедію міжнародного права [3]. Енциклопедія Інституту Макса Планка містить близько 1300 статей з різноманітних аспектів міжнародного права. Енциклопедія багато у чому базувалась на німецькій традиції і школі міжнародного права; зокрема, як зазначали іiі автори, на вихід цієї праці вплинули енциклопедичні видання німецьких класиків міжнародного права К.Штруппа (1924-1929) та Г.-Ю.Шлохауера (1960-1962). Утім метою цієї роботи стало «висвітлення і пояснення як традиційних, так і нових аспектів, норм та інститутів міжнародного права» [3, Vol. 1, P. vi].

Тривалий період дана праця залишалась єдиним класичним енциклопедичним виданням 3 міжнародного права. Утім стрімкий розвиток цього права потребував оновлення енциклопедичного матеріалу. Так, 2012 року дану Енциклопедію було оновлено і перевидано (при чому за вимогою часу текст перевидання є доступним онлайн [4]), що відразу було сприйнято науковою спільнотою «як непересічна подія в міжнародно-правовому академічному житті» [5; 6]. При цьому слід відзначити, що видання Енциклопедії Інституту Макса Планка є справді універсальним, до нього було залучено фахівців і ресурси з різних країн світу.

УДК 341.645 .2

https://doi.org/10.36952/uail.2020.3.165-168

\section{ЦИБУЛЕНКО Євген}

доктор права, професор, старший ментор юридичного інституту Талліннського технічного університету, професор Київського міжнародного університету (Таллінн, Естонія)

ЛОБОДА Ксенія

кандидат юридичних наук, головний консультант секретаріату комітету Верховної Ради України з питань соціальної політики та захисту прав ветеранів 
Тому роботу над публікацією рецензованої української «Енциклопедії міжнародного права» можна назвати сподвижнецькою працею.

Видання вітчизняної «Енциклопедії міжнародного права» здійснене за редакцією Директора Інституту держави і права ім. В. М. Корецького НАН України, академіка Національної академії наук України Ю. Шемшученка та доктора юридичних наук, професора, члена-кореспондента Національної академії правових наук України В. Денисова.

Рецензована Енциклопедія є першим в Україні системним зводом термінів з міжнародного публічного права. Це суто українське видання в якому проаналізовано міжнародно-правові документи, які $\epsilon$ чинними для України. Авторами було проаналізовано колосальний обсяг міжнародно-правових джерел і спеціальної юридичної літератури у сфері міжнародного права. Варто зазначити, що це енциклопедичне видання вирізняється високим рівнем правової культури, методологічною майстерністю вирішення завдань, глибокою теоретичною розробкою основних проблем міжнародного права та водночас практичною спрямованістю.

У той же час варто зазначити, що сучасне міжнародне право, незважаючи на окремі його недоліки, в інтелектуальному і прикладному плані ще далеко не реалізувало свої великі потенційні та реальні можливості. За своєю правовою природою та засадничими началами воно є глибоко демократичним, прогресивним та цивілізаційним.

На винятково позитивну оцінку заслуговує те, що у виданні містяться статті практично по всім міжнародно -правовим угодам, якими регулюються міждержавні, дипломатичні та договірні відносини України з іншими країнами. Перевагою Енциклопедії є те, що в ній здійснено грунтовний аналіз судової практики Міжнародного Суду ООН, Постійної палати міжнародного правосуддя, без винятку всіх європейських інституцій та інших міжнародних юрисдикційних органів.

Енциклопедія міжнародного права є актуальним виданням, яке має наукову і практичну цінність. Авторським колективом здійснено вагомий внесок у вирішення актуальних проблем сучасної теорії $\mathrm{i}$ практики міжнародного права. Енциклопедія міжнародного права з успіхом може використовуватися у вищих навчальних закладах під час вивчення загального

курсу міжнародного права та галузевих міжнародно-правових дисциплін, а також бути корисною для українських дипломатів і суддів, які розглядають справи, що пов'язані із застосуванням норм міжнародного права у національній правовій системі України. Також, необхідно відзначити, що це видання приверне увагу різних категорій читачів.

Утім, вважаємо дискусійною позицію авторів щодо приділення надмірної уваги системі міжнародного права держави-агресора Російській Федерації (далі-РФ). Зокрема в Енциклопедії велика кількість статей присвячена біографічним даним юристів-міжнародників часів РСФСР та сучасної РФ (А.Х.Абашідзе, В.С.Верещетін, О.М.Вилегжанін, та ін.), і водночас відсутні статті про визначних вітчизняних фахівців (В.І.Кисіля, В.Преображенську Г.Рошковського та ін.).

Викликає подив широке представлення діяльності таких установ РФ як Дипломатична академія МЗС РФ та Інститут держави і права РАН, котрі насьогодні є флагманами антиукраїнської політики та виправдання грубих порушень Росією міжнародного права, таких, як агресія проти Грузії та України [див. про це: 7, С. 487-494].

Не менш дивним стало побачити поміж імен авторів Енциклопедії - шановних і знаних в Україні та за кордоном фахівців, також імена одіозних осіб. А саме: російських професорів В.Л.Толстих (статті «Алабама 1872» та «Воєнна і воєнного характеру діяльність у Нікарагуа та проти неї 1984 i $1986 »)$ та О.О.Моїсеєва (стаття «Дипломатична академія Міністерства закордонних справ РФ»). Достатньо згадати, що В.Л.Толстих є не лише адептом ідеї «розпаду української державності», але й лауреатом знаку «За усердие» II ступеню - «За взаимопонимание и поддержку, сопереживание за судьбу Луганской Народной Республики», врученого йому особисто терористом І.Плотницьким. О.Моїсеєв в якості декана факультету міжнародного права Дипломатичної академії МЗС РФ та віце-президента Російської асоціації міжнародного права є послідовним утверджувачем сучасної російської ідеології міжнародного права, що базується на запереченні імперативних принципів цього права та виправданні його грубих порушень [8].

Доволі архаїчним є і трактування у виданні Жовтневої революції 1917 року в Росії, як «масштабного світового процесу, що мав на меті зрівняти історичні шанси всіх народів на шляху до світової соціалістичної революції». А теза про те, що ця революція має велике значення для України, зокрема «для ії утвердження як суб'єкта міжнародного права - спочатку у вигляді Української Народної Республіки з ііі прагненням до творення нової федерації народів у складі демократичної Росії а згодом союзної республіки у складі СРСР» не лише не відповідає історичним фактам, але й з міжнародно-правової точки зору була беззаперечно спростована професором О.В.Задорожнім у праці «Генеза міжнародної правосуб'єктності України» [9]. 
Тим більше дивною видається відсутність теми анексії РФ АРК Крим та війни на Донбасі при розкритті відповідних понять та категорій (в статтях «Анексія» та «Агресія» наведено значну кількість прикладів по всьому світу, крім подій 2014 р. в Криму та на Сході України, при тому, що в статті «Агресія» все ж таки згадано про те, що «Міжцивілізаційний конфлікт, загострення якого припало на листопад 2013 - травень 2014рр., призвело до включення Криму до складу РФ»). У той же час, вітчизняні і зарубіжні юристи-міжнародники (як і авторитетні міжнародні організації - Генеральна Асамблея ООН, Рада Свропи, Міжнародний кримінальний суд та ін.) вже чітко довели, що відбувся саме акт агресії Росії проти України внаслідок якого має місце збройний конфлікт міжнародного характеру [10; 11].

Так само відсутні посилання на ці події в якості можливого прикладу при розкритті таких термінів як «експропріація»; «зловживання правом», «вето», «воюючі сторони», «принцип добросовісного виконання міжнародних зобов' язань» та ін.); можна вказати і на недостатнє висвітлення війни на Донбасі при розкритті відповідних категорій (в статті «Імплементація міжнародно-правових зобов'язань України у сфері міжнародного гуманітарного права» зазначено просто, що є «збройний конфлікт на території України», знову ж таки без уточнення, що даний збройний конфлікт має саме міжнародний характер).

Велика частина критичних зауважень відноситься до першого тому 2014 року, матеріали якого почали готувати до друку ще до російської агресії, тим не менш, серйозність ситуації безумовно вимагала оперативного внесення змін.

Не може не викликати здивування трактування статусу Абхазії в однойменній статті, автор якої зазначає, що «можна констатувати, що Республіка Абхазія здобула неповне міжнародне визнання, тобто іiі міжнародно-правовий статус залишається проблемою міжнародного співтовариства, і подальший процес ії визнання залежить більше від політичних, ніж юридичних чинників» (якщо, звісно під «неповним визнанням» не розуміти визнання низкою терористичних організацій та 5 державами, включно з Росією, яка встановила на цій території свій маріонетковий режим).

Ці та інші положення Енциклопедії свідчать про можливість і необхідність подальшої роботи над просуванням енциклопедичної міжнародно-правової літератури в Україні із ретельним підходом до відбору авторів та справді правових і актуальних позицій та концепцій.

Крім того, дане видання великою мірою виграло б, якби, на зразок «Encyclopedia of Public International Law» 2012 року, його було представлено і в онлайн варіанті. Тому авторам хотілося б побажати здійснити видання «Енциклопедії міжнародного права» в електронному вигляді, що значно б збільшило їі доступність для великого кола читачів та розширило б їі аудиторію.

Безумовно одним із викликів для публікації Енциклопедій з міжнародного права є стрімкий розвиток останнього та зміни в міжнародних відносинах. Це не стало перешкодою авторам рецензованого видання, і більшість його статей не підпадають під ризик стати застарілими. А можливе врахування побажання перевести видання в електронний формат дозволить динамічно оновлювати і доповнювати енциклопедичний матеріал.

У цілому ж, видання Енциклопедії міжнародного права у 3-х томах суттєво зменшує існуючий дефіцит інформації у сфері міжнародного права. Безперечно, що вона буде корисною як для дипломатів, науковців, викладачів, аспірантів і студентів, що опікуються проблемами міжнародного права, так і для широкого кола читачів, які цікавляться актуальними проблемами міжнародного права.

Загалом звернення української науки до енциклопедичного жанру свідчить про новий імпульс у розвитку вітчизняної доктрини. Як згадувалось на початку цієї рецензії, не кожна національна школа міжнародного права здатна на заповнення усіх науково-практичних потреб - теоретико-доктринальних, навчально-методичних, періодичних, енциклопедичних видань. Нещодавно в Україні було активно поновлено публікацію підручників 3 міжнародного права [див. зокрема: 12; 13]; видавнича активність у сфері міжнародно-правової теорії та періодики не припиняється. А як показала публікація тритомної «Енциклопедії міжнародного права» сьогодні вже по усім вказаним напрямам українська наука здатна розвиватись на належному і конкурентному рівні.

1. В. Буткевич. Щорічник як новий рівень української науки міжнародного права // Український щорічник міжнародного права. - 2007. - К.: Українська Асоціація міжнародного права; Видавничий дім «Промені», 2010.

2. Словарь международного права / Дипломат. акад. МИД СССР; [М. М. Аваков и др.]. - 2-е изд., перераб. и доп. - М. : Междунар. отношения, 1986. - 432 с.

3. Encyclopedia of Public International Law. In 5 Volumes. - Published under the auspices of Max Planck for Comparative Public Law and International Law under the direction of Rudolf Bernhardt. - Elsiever Science Publishers. - 1992-1999. 
4. The Max Planck Encyclopedias of International Law. Available at: https://opil.ouplaw.com/home/ mpil. Accessed on: 25.09.2020.

5. Yinan Bao. The Max Planck Encyclopedia of Public International Law. Second printed edition. Available at: https://journals.sas.ac.uk/lawreview/article/view/1700. Accessed on: 25.09.2020.

6. Sean D. Murphy. Book Review of The Max Planck Encyclopedia of Public International Law (Rüdiger Wolfrum, ed. 2012) in 107 American Journal of International Law 510 (2013). Available at: https:/ / scholarship. law.gwu.edu/cgi/viewcontent.cgi?referer=https:/ / en.wikipedia.org/\&httpsredir=1\&article=2115\&context =faculty_publications. Accessed on: 25.09.2020.

7. Українська Революція гідності, агресія РФ і міжнародне право. - К.: К.І.С., 2014. - 1016 C.

8. Моисеев А. О некоторых международно-правовых позициях по украинскому вопросу // Международная жизнь. Available at: https:/ /interaffairs.ru/jauthor/material/1063. Accessed on: 25.09.2020.

9. Задорожній О.В. Генеза міжнародної правосуб'єктності України: монографія / Задорожній Олександр Вікторович ; Укр. асоц. міжнар. права, Ін-т міжнар. відносин Київ. нац. ун-ту ім. Тараса Шевченка, Каф. міжнар. права. - Київ : К.І.С., 2014. - 688 с.

10. Tsybulenko E., Francis J.A. (2018) Separatists or Russian Troops and Local Collaborators? Russian Aggression in Ukraine: The Problem of Definitions. In: Sayapin S., Tsybulenko E. (eds) The Use of Force against Ukraine and International Law. T.M.C. Asser Press/Springer, The Hague, pp. 123-144

11. Tsybulenko E., Kelichavyi B. (2018) International Legal Dimensions of the Russian Occupation of Crimea. In: Sayapin S., Tsybulenko E. (eds) The Use of Force against Ukraine and International Law. T.M.C. Asser Press/Springer, The Hague, pp. 277-296

12. Міжнародне публічне право : підручник : у 2 т. / [В. В. Мицик, М. В. Буроменський, О.В.Буткевич та ін.]; за заг. ред. В. В. Мицика. - Харків : Право, 2019. Т. 1 : Основи теорії. - 416 С.

13. Міжнародне публічне право : підручник : у 2 т. / [В. В. Мицик, М. В. Буроменський, М. М. Гнатовський та ін.]; за заг. ред. В. В. Мицика. - Харків : Право, 2018. Т. 2 : Основні галузі. - 2018. - 624 с. 